\title{
A Big Battle: The State vs. Indigenous People (Case Study in Jambi Province)
}

\author{
M. Yusuf ${ }^{1}$, Syafrial $^{2}$ \\ ${ }^{1}$ Department of Government Studies, Universitas Jambi \\ (email: myusuf@unja.ac.id) \\ ${ }^{2}$ Department of Government Studies, STISIP Nurdin Hamzah \\ (email: syafri2009@gmail.com)
}

\begin{abstract}
The change in designation of Bukit Duabelas area into Bukit Duabelas National Park in Jambi province raises a conflict between the national park official who was ruling the zonation system in the national park and the Orang Rimba people who have lived there for many years. The decision of the protected area aims to preserve the life and culture of Orang Rimba. However, zoning rules in the field are interpreted as an effort to limit space and access to the forest resources for Orang Rimba who have traditionally utilized them. This research uses a case study approach to explore the dynamics of conflict on the protected area. The results of the study show that conflicts in national park management are very dynamic because of shifting disagreement about the protection area. The conflicts began with debates about the zoning system which led into the fight for access to the park resources which were contested over the concept of national parks and customary forests. This paper argues the battle over the national park was not only about contested natural resources but also was a fight for authority and power between the state and indigenous people over the concept of park management.
\end{abstract}

\section{Keywords:}

forest resources; conflict; access; national park

\section{Introduction}

This paper analyzes the dynamics of conflict over the Bukit Duabelas National Park (BDNP) in Jambi province. This research is relevant in the context of Southeast Asia because concerns and conflicts about access and the distribution of natural resources have arisen almost everywhere (Drahmoune, 2013). In the local context, since 2004, conflicts have occured between the government and indigenous peoples in the utilization of forest resources. In 2004 national park officials managed the BDNP through the national park management plan (NPMP) document. Orang Rimba resisted the document plan until 2008 because it limited them in utilizing forest resources, so in 2009 national park officials revised the document plan that involved Orang Rimba.

After the joint agreement, conflicts continue to arise dynamically. A joint agreement involving the Orang Rimba was only a formality. The national park official (NPO) did not use Orang Rimba's aspiration as a reference in decision making; the decision prioritizes the state orientation. The NPMP document includes increasingly stringent rules. The rule regulates that Orang Rimba be placed in traditional utilization zones, then they would not be allowed to access resources in another zone.

The NPO decided that the area had to be sterile from human activities except for 
traditional utilization zones, while about 3000 Orang Rimba living in the area use forest resources to sustain their life through plantation, agriculture and gathering food activities in all zones. All types of agricultural activities are prohibited by law because of its impacts on deforestation of the protection area (Steinebach \& Kunz, 2017). On the other hand, Orang Rimba argue that their utilization of the area will not threaten the existence of a national park because it is only for their livelihood. These two perceptions are very different which is why conflicts continuously arise between the NPO and Orang Rimba.

Access over natural resources has an impact on life expectancy, wealth distribution, power structure, and group identity allegedly as a source of conflict. The way to minimize the conflict is to protect and manage natural resources in a sustainable way as well as to improve a decent life. These steps are considered useful to decrease the cause of conflict that involve those who want to profit from the natural resources. In practice, the conservation policy is commonly exacerbating the condition and leads to conflict in implementation. Conflict over forest resources often occurs among the community, state, and company because both sides claim rights to the land based on strong arguments (Yasmi, Kelley, \& Enters, 2011)

Conservation is correlated to power and production both at the local and global level. Preservation is considered as protection for flora and fauna. On the other hand, conservation is an effort to maintain the country's foreign exchange and economic resources. These different assumptions indicate that protection creates a space for a social relationship that contains different interests of various stakeholders. These conditions provide opportunities to obtain natural resources using multiple forms of power (Darmanto, 2011).

In the implementation process of conservation, the protection aspect of the national park is more in the forefront, hence the sustainable utilization of forest resources, and its ecosystem is not getting significant portion yet (Prabowo, Basuni, \& Suharjito, 2010). Conservation at the end has limited community access to natural resources as a source of their livelihood. The limitation of access through a zoning system places people in an area where they are not allowed to use other regional resources. Conservation creates injustice in the distribution of profits; the government utilizes areas that contribute to state revenues, while people are not able to benefit from it (Hammill, Craig, Malpas, \& Matthew, 2009).

In the beginning, the establishment of conservation areas in a national park triggered conflict because of its centralistic management. Conflict resolution is likely to use an adjudication process; hence, new conflict evolves when different models come up after the completion (Sembiring, Basuni, \& Soekmadi, 2010). New conflicts that arise are more dynamic because of an accumulation of previously unresolved problems coupled with new and more complicated problems.

Studies that address fights regarding access to land are focused on the interaction between government and local communities. It shows that government institutions contested access to power from each other in recognition of land. This condition provides an opportunity for the community to claim the land using various strategies such as adat law, confrontations, and disputing state claims (Bakker \& Moniaga, 2010) In contrast with other research, it shows that the state fails in utilize forest management, while the community cannot use forest resources because the government only supports the company (Purnomo \& Anand, 2014). Another study analyzed the struggle of land claims between indigenous people and a palm oil company. The article shows that access to land results from recognition but different institutions and asymmetric powers lead to equilibrium conditions (Beckert, Dittrich, \& Adiwibowo, 2014). 
The research focuses on causes, dynamics, and consequences of social conflicts regarding the use of forest resources which mostly damage the existence of protected areas and the life of communities. Policies that prioritize protection of forest management causes conflicts between state and the local community whose life in the area (Sardi, 2010). The next study focused on the history of natural resource conflict which shows that conflicts about forest natural resources are caused by different perceptions, different values, different interests, and differences in recognition of ownership rights (Marina \& Dharmawan, 2011).

In contrast to both research (Marina \& Dharmawan, 2011; Sardi, 2010) illustrated above, the study of land conflict resolution argues that land is de jure owned by the state, but in defacto on land where there are humans, closed access becomes open (Harun \& Dwiprabowo, 2014). In connection with the results of the study, research focusing on conflict resolution argued that the zoning system had accommodated the aspirations of all stakeholders thus there was no conflict among stakeholders (Sembiring et al., 2010).

Research that examines resistance to government policies shows that strict and rigid regulations lead to the emergence of indigenous peoples' opposition to the state based on adat law (Senjaya, 2011). Another study that focuses on responses to policies also argues that a community has the power to empower itself to achieve its goals and not just accept state policies (Rokhdian, 2012). Both studies show state policies that limit and harm the indigenous people to prevent access to the forest resources leads the indigenous' resistance.

The previous studies indicate that there is no research on the dynamics of conflict over natural resources utilization in the protected area. Thus, there is an opportunity for further research about national park management (NPM) that exists in the utilization of natural resources. This research is unique because it discusses one of the conflicts over the management of natural resources in the protected forest, which are not justified by Indonesian law. This paper presents the struggle of the state's power with indigenous peoples towards the utilization of forest resources. BDNP is unique because it is one of the national parks in Indonesia, where indigenous people live inside the area, and their life depends on forest resources.

Community analysis using the perspective of conflict, starting with the fact that members can be grouped into two categories, namely, people in power and people who are controlled. That dualism is included in the structure of interests, which results in different benefits and may contradict each other. In turn, the differentiation of interests can give birth to clashing groups (Veeger, 1990).

Conflict is a difference in perception of interests or a belief that the aspirations of the conflicting parties cannot be achieved simultaneously (Pruitt \& Rubin, 2004). The conflict consists of perceptions, desires, and involved parties. To understand conflict dynamics is to look at the source of conflict, namely everything that is at the core of problems such as natural resources. After the source of the conflict, the next step is to identify the character of the relationship between the various parties in disagreement (Susan, 2009).

Analysis of conflict dynamics uses the aggressor-defender model, spiralconflict model, and structural change model. The aggressor-defender model draws a distinguishing line between the two conflicting parties. Aggressors are considered to have goals that cause them to be in conflict with the defender. The spiral-conflict model explains that escalation is a circle between action and reaction, then the model of structural change, explains that conflict produces residues in the form of changes that happen to the parties in conflict. This residue will encourage advanced contentious behavior that has equal or higher 
levels, which reduces efforts to seek conflict resolution (Pruitt \& Rubin, 2004).

Conflict plays a central role between models of decision making; it is equally relevant when distinguishing between descriptions of the implementation process. Rational models and bureaucratic politics make decisions for individuals when they don't have a vested interest. Policy conflicts will occur when more than one organization sees the policy as something relevant to their interests and when the organization has an inappropriate view. Disputes in the procedure can develop over the issue of jurisdiction or more likely the substance of the means proposed to achieve the objectives. The intensity of the conflict increases with a rise in the incompatibility of concerns, and with an increase in the stakes felt for each party (Matland, 1995).

The most crucial process in society is the occurrence of class conflicts. A group that rules has a position and controls the means of production that are important for the survival of the community. A battle is a social process in which individuals or groups try to fulfill their objectives through disagreements or conflicts with their opponents accompanied by threats and or violence. Conflict includes a stage in which there is a conflict of rights over wealth, power and position. Ultimately, one party tries to destroy the other party (Jemahat \& Si, 2018).

Conflict in the context of the national park is commonly related to the struggle for access to resources. Access refers to all capabilities that allow getting benefit from goods. Access is sourced from the ways, relationships, and processes that enable profit. Access analysis involves identifying and mapping specific profit streams of interest, identifying the mechanisms of different actors involved in acquiring, controlling, and maintaining the flow of profits and distribution and recognizing the power relations that underlie the access mechanisms involved in the event (Agung, 2011; Larson, 2013; Ribot \& Peluso, 2003).
Conflict is a fight between two or more parties, which is caused by differences in perspectives, interests, values, status, power, and scarcity of resources. The actor or party in the conflict is then called the subject of the disagreement. Conflict subjects are defined as parties involved in land tenure system conflicts that affect or influence the process so that the analysis includes those who directly have land rights (main actors) and actors who have influence to strengthen claims behind other rights (supporting actors).

\section{Methods}

This paper is exploratory qualitative research which aims to get a better understanding of the particular phenomenon, with a case study approach. Case studies are practiced so that researchers can describe the complexity of community activities that represent the meaning of each social actor (Stark \& Torrance, 2005). Data was collected from three villages, namely: Sei Ruan Ulu village (Batanghari district), Pematang Kabau village (Sarolangun district) and Tanah Garo village (Tebo district). Data sources gathered from 1). The primary data was derived from a structured and unstructured interview and combined with observation. Through a combination of interview and observation methods, the writer tried to explore data insightfully; 2). Secondary data was obtained from previous research results, including journals, bulletins, newspapers, books, regulations, internet and other supporting resources.

The data was collected by determining the key-person and used the snowball sampling technique by asking an informant references. The informant should have information about the object of the research such as national park official, the Orang Rimba, KKI Warsi, Sokola Rimba, villagers (the local community in Sei Ruan Ulu villager, Tanah Garo village and Pematang Kabau village). The informants were set based on the criteria, firstly: officials 
that represent the state as the regulator and the implementer of NPMP document who has direct interaction with the Orang Rimba. Secondly, the Orang Rimba as forest dwellers who are against the policy in the BDNP management plan. Thirdly: NGO KKI Warsi and Sokola Rimba which have conducted lots of research studies, publications, and education provisions, indigenous rights advocacy and other mentoring activities. Fourthly: local community in Sei Ruan Ulu, Tanah Garo, and Pematang Kabau villages, these three villages are the access door for Orang Rimba and also serve as a community partner of the forest range (CPFR).

The data was analyzed using an interactive model which included coding and reduction; this step was made to facilitate the mapping of conflict shifting. Then proceeding and presentation is done by dividing the dynamic of conflict based on time and developing issues. Description of conflict phases is intended to facilitate the process of identifying actors who are directly and indirectly involved. After the presentation, the data was organized sequentially, the next step is a withdrawal of conclusion and data verification. At the end of this section, this article will recommend ways of solving the conflict that occurs in the Bukit Duabelas National Park.

\section{Results and Discussion}

\section{The emergence of conflict}

The Bukit Duabelas is a national park that has around 60,500 ha located in 3 districts namely: in Batanghari regency approximately 65\%: 37,000 ha, in Sarolangun regency approximately 15\%: 9,000 ha and in Tebo regency approximately $20 \%: 11,500$ ha. In Forestry Ministry decree No. 258/Kpts-II/2000, dated $23^{\text {rd }}$ August 2003, it was expressly stated that the area of BDNP is expanded into 60,500 ha and designated as a National Park which was a limited production forest with 20,700 ha, production forest 11,400 ha, the other land use area 1,200 ha and natural Preservation and Nature Sanctuary/Reserve Biosphere 27,200 ha (Bakker \& Moniaga, 2010; Sylviani, 2008).

The emergence of hidden conflicts begins from government policies with a centralized decision. Centralized management decisions that prioritize conservation trigger the birth of conflict because they ignore community involvement (Sembiring et al., 2010). In December 2004, the Directorate General of Forest Protection and Nature Conservation (FPNC), the district head of Sarolangun regency, the district head of Tebo regency, the district head of Batanghari regency, and NRCC Jambi established Bukit Duabelas National Park Management Plan (BDNPMP). The policy is a guideline for managing the protected area which was socialized on $22^{\text {nd }}$ to $23^{\text {rd }}$ August 2005 (for the workshop both NRCC and KKI Warsi), then on $24^{\text {th }}$ August 2005, it was disseminated to the Orang Rimba.

After the socialization of the zoning system, the conflict began between the government (NRCC) and Orang Rimba who traditionally used and regulated forest areas, and the claims of rural people who live in buffer zones of national parks. At the beginning of the conflict the issue was raised about differences in concepts about the BDNP zoning system. This difference presents different concepts with different claims. Each actor competes with each other in the distribution of regions based on their interests. In this context, the actors compete for power over regional allegations based on their rules (Darmanto, 2011).

NRCC is an institution that has legitimacy representing the state to decide the pattern of NPM through BDNPMP documents that regulate the zoning system. The zoning system is divided into core zones, jungle zones, rehabilitation zones and utilization zones (areas designated for Orang Rimba). While the Orang Rimba also have claims based on history and customary law that they have the right to regulate because they have lived in the area 
for a long time. Orang Rimba manages Bukit Duabelas areas for their customary lands and traditional ceremonies such as tano peranokon (place of birth), balo balai (wedding venue), a land for agriculture and plantations, areas of inum-inum (source of water) and locations for growing fruits (Takiddin, 2014). The division system of the territory was based on functions of the area in each region. Therefore the Orang Rimba claim does not have a standard administrative function in the dividing area.

Unlike the Orang Rimba, rural communities faced the reality of uncertainty over territorial claims. This uncertainty arises because of the transition of regions based on the marga area (Jambi indigenous peoples' association/rechtsgemeeshap) into the village boundaries. Between areas which were previously regulated before independence differed from the territorial system controlled after independence. In this context, there has not been any conflict among the government and the people who lived in the buffer zone.

Land conflicts happened because of the unclear land boundaries (Jemahat \& Si, 2018), the overlapping of land claims between the zone system, claims based on customary land, and claims based on the village area or clan area in the NPM were the primary source of conflict. The conflict was strengthened through disagreements regarding forest resources that could be used by people who live in them and communities in the buffer zone. On the sidelines of differences in boundary claims, each actor in the conflict utilized the situation for existing resources which has implications for the threat of the existence of a national park.

According to NRCC, the process of socializing the BDNPMP policy is following procedures, and it invited stakeholders of the national park (rural community, Orang Rimba, NGOs, and related stakeholder). After the socialization of the conflict began, the Orang Rimba that assisted by the NGO of Sokola Rimba filed an objection to the zoning system directed to the Head of Conservation Section Bangko district, NRCC Jambi and Director General of FPNC. They criticized the RPTNBD and asked for a revision of the documented plan. The policy to change the forests functioned in conservation areas aimed to protect its biodiversity and ecosystem from extinction to optimize forest function and benefits sustainably (Sylviani, 2008). The process of changing status did not involve the stakeholders, policies limited the space of the Orang Rimba (they could only be in the utilization zone).

The legitimacy of land tenure of the area becomes very important because it related to the future and survival of life. Orang Rimba did not live in one place because some times they did melangun (go away because of an accident), avoid enemies, open new fields with shifting patterns. These activities have been going on for a long time and were maintained as customary claims as well as being a weapon against various forces who want to make claims against their territory (Steinebach, 2013).

The presence of the NGO of Sokola Rimba in this context can be as an actor in the conflict, its contribution to providing input to the Orang Rimba about the importance of reaffirming the concept of adat in managing their life in a place. Even though they do not directly exist in the conflict, their support for the Orang Rimba through assistance during the advocacy process makes them part of the conflict. After the BDNPMP document was published, the NGO of Sokola Rimba read over the contents of the document, which basically according to them, the zoning system harmed the Orang Rimba. This issue is the first start of the conflict among the two main actors; this issue is strengthened through the existence of various acts of control from the NRCC.

\section{Escalation of the conflict}

In this phase, the conflict began with a shifting; if the previous conflict concentrated 
on the debate of the zoning system, then in this stage, the conflict started the struggle for access to forest resources. The continuing process of attacking each other emerged with the single action of the NPO to the Orang Rimba plants. The action is a very fundamental reason because it refers to the Law of the Republic of Indonesia No. 41/1999 concerning Forestry and was based on BDNPMP document. However, it turns out that the action of land control has implications for the hearts of the Orang Rimba because they have spent energy and spent time to do it.

In November 2005, manifest conflicts began, which started with various actions to control land use for agricultural activities by the government. NRCC staff revoked rubber trees in the Keruh River area belonging to Depati Ngerak, at the Singosari road in Pematang Kabau village, Air Hitam District. In the same month, the Melayar field located on the Keruh Ilir river (in the Kediri road, Pematang Kabau village) was also regulated. The following year, around April to June 2006, the NRC Staff banned the Neka Family, Mandum and Merau from opening fields at the Bukit Suban. The following month the NRCC staff banned the Mapo, Bedaro, and Berendam families from opening in the Keruh Ulu river area (Pematang Kabau village).

These various controls reinforce the argument that the zoning system hurts Orang Rimba while at the same time positions the NRCC as a common enemy. This control impacts the emergence of collective awareness and collective movement to criticize state authority (Anjarwati, 2008). The emerging resistance can be negotiations which then evolve into the use of formal legal instruments, acts of violence, mass blockade (Cote \& Cliche, 2011). It began from temenggung Majid (temenggung is head in a group of Orang Rimba), this awareness extends to other groups. Orang Rimba consolidated to manifest a movement to prosecute plant destruction. Walhi Jambi, PHBI Sokola Rimba,
PPJ Jambi, and PHBI West Sumatra assisted with the action. KKI Warsi, which has had an education and health mission since 1996, they (Orang Rimba) assume it is in part of the NRCC. On the other hand, specific activities require using a mystical weapon, threatening, and destruction of NRCC plants, asking for wages and compensation, pretending nothing happened and all these reactions were done to secure the right of access to economic resources (Senjaya, 2011).

At least two important issues that cause they life can not be separated from the forest. The First, the economic problems that's become the foundation of survival as a place of hunting, gathering, and to use forest products became the most important economic resource in their activity. Second. Forest becomes the identity of life in running a variety of wisdom traditions and culture that bequeathed by the founding fathers as a guide in carrying out the significance of life for Orang Rimba.

The charge for crop destruction did not get a positive response from NRCC because their existence estimated the impact on deforestation. Contentions increased until re-discussion of the NPMP document through a negotiation process. The process was accompanied by Walhi Jambi, NGO of Sokola Rimba, PPJ and PHBI West Sumatra which also did not reach a common understanding. As a result, the claim became more extensive, the climax which was the Orang Rimba charging customary punishments of 2,200 pieces of cloth for plant destruction by the NRCC Staff. All accusations turned out to be unfulfilled, so the Orang Rimba blocked the NRCC staff, they forbade NRCC staff from entering the area. At the climax of the conflict, the Orang Rimba made a more massive movement; they began to hold demonstrations until in September 2006 they filed the claim with the National Human Rights Commission (NHRC) in Jakarta.

Accusations for got a response from NHRC, the study from the NHRC shows that at 
least 13 rights were violated during the drafting and policy setting (KomnasHAM, 2007). The most crucial one is the loss of indigenous sacred land. The results of NHRC's study gave them confidence that they had public support. In this position, the Orang Rimba feel they won the power struggle over the conflict of park resources. The victory adds to the belief that they are entitled to regulate and manage national parks based on concepts that they have applied for generations.

Together with the emergence of claims, in 2006, the Bukit Duabelas National Park Office (BDNPO) formed through the Forestry Minister's regulation number P.29/Menhut/ II/2006 and its active duties at the beginning of 2007. Tasks were transferred from NRCC to the BDNPO, a transfer of power from the NRCC to the BDNPO affects the dynamics of the conflict among them. Various conflicts ended without a resolution. However, it does not mean that the battle has stopped; the process of authority transferring from the NRCC to the BDNPO gave new hope for future management but also initiated a new round of conflict.

During the transition, the Orang Rimba utilized the situation to strengthen support from various NGOs who had accompanied them. Moreover, with the utilization of forest resources, they take the benefit of opportunities during the emptiness of authority when the transition process that runs for approximately one year. At this moment, KKI Warsi establishes communication with people after previously, they considered to be in favor of the NRCC policy. This effort gets results, KKI Warsi succeeded in mediating between actors who delivered conflict resolution through joint agreement.

\section{Joint Agreement}

After the transition of the NPM from the NRCC to the BDNPO, new hope is emerging about the future of the relationship between the Orang Rimba and the NPO. In December
2009, the conflict resolution process continued with a joint agreement between the Orang Rimba and the NPO regarding changes and placement of zoning functions. The joint deal broadly revised the BDNPMP document with several main points, namely: mutual agreement to protect, mutual agreement acknowledging that to administer BDNP through the BDNPMP document, the joint agreement recognizes the zoning system, the core zone that contains Orang Rimba not included in the core zone, Orang Rimba will not divert land or gardens to other than outsiders (village communities), do not carry out illegal logging activities or assist in the area (Balai Taman Nasional Bukit Duabelas, 2009).

The agreement that was described above is a new round of NPM which at least has begun to be carried out in a participatory manner. The issue of the zoning system, which was opposed by the Orang Rimba since the beginning of the document being legalized has been met with an agreement. Likewise, the utilization of forest resources, which previously became the cause of escalation of conflict has also been mutually agreed upon as stated in the new BDNPMP.

There are consequences after a joint agreement, the NPO performs the task of implementing a more stringent system that reaffirms the existence of conservation areas. The impact of the revised BDNPMP implementation has raised the issue of limiting access to the use of forest resources. Even rumors emerged about the expulsion of Orang Rimba from their ancestral lands. This belief is reinforced by the government programs that provide residential areas such as those in the Batanghari area (Jelitai group), and the Sarolangun (Rahman group) which are considered to be one form of eviction from their home (Bukit Duabelas). The program is indeed coming from the Ministry of Social Affairs but still is interpreted as a government agenda (NPO) to remove them from their traditional areas used for hunting and gathering. 
Some of the Orang Rimba (such as Temenggung Majid, Betaring and members) assumed that the process of resolving conflicts through joint co-ordination did not involve all Orang Rimba (representatives of each group) in the decision making. Another side, is the Ministry of Agriculture decree No 258/kptsII/2000 which mandated the Park as "a place of living for Orang Rimba". There is a major weakness in the decree which is stated in very common alignment sentences. This decision is used as a reference for exploiting forest resources in no small measure. The weakness in the decree is evident from a ubiquitous statement. The decision written in the document is used as a reference for exploiting the large majority of forest resources.

\section{Reappearance of conflict}

The conflict dynamics over the NPM experience changes in orientation from the parties involved. The leading causes of conflict are often overlapping claims of land tenure, conservation policies, and economic development that prioritize global and national interests. The roots of conflict also include asset destruction, loss of income and livelihood opportunities, and displacement of people from local communities (Yasmi et al., 2011). In many instances local communities and indigenous peoples suffer the most when such conflicts play out. The biggest challenge is finding acceptable, fair and lasting solutions. Focusing on how rights (or a lack thereof).

After a joint agreement, conflicts about the concept of zoning still arise because it does not involve all the Orang Rimba, but the zoning system is not the main issue of conflict. Over time, the zoning system was ignored by Orang Rimba, because it only spent energy. In this phase, the conflict leads to the struggle for access to forest resources. Due to past conflict such as cutting down the rubber trees a few years ago before a joint agreement was made by NRCC. The awareness of the importance of controlling forest resources has increased, marked by the intensity of clearing land for a new farm and garden. Awareness of the importance of access is strengthened by the case of re-destruction of Orang Rimba plants. In this context, the emergence of indigenous claims-based resistance to fight for rights is dominant to face the government policy (Afiff \& Lowe, 2007).

The tension happened again in 2011; the NPO destroyed farms that did not belong to Orang Rimba, the plants on the land were owned by villagers who employed Orang Rimba as landholders. The owners put pressure on Orang Rimba, then they committed violent acts against the forest rangers at the Air Hitam resort (sub unit office of BDNPO). Not long after that, Orang Rimba held a demonstration against NPO due to their disappointment against forest encroachment undertaken by Non-Orang Rimba parties. In the same year, the joint raids were conducted which resulted in the burning down of the community's house which was located in the conservation area, then the local community mobilized Orang Rimba to do a demonstration at SPA resort (sub unit office of BDNPO). Not long after that, in 2013 unscrupulous military personnel cleared around 30 ha of forest in the Park; however, this case did not affect the issue broadly. It showed how the NPO has become more complicated by the involvement of unscrupulous apparatus and tactics.

The Orang Rimba responded to the treatment of NPO by clearing the land and cutting trees down continuously to plant with crops such as rubber trees and rice. NPO responds to land clearing by issuing land clearing policies that regulate the maximum extent of land clearing for plantations for jungle people. Land clearing is allowed for up to a maximum of 2 hectares for each person, the area cannot be traded or delegated to other people than Orang Rimba or the land can be worked that is owned by villagers in the 
national park. The regulation, which limited clearing a maximum of 2 hectares of land, is assumed to limit their economic rights, and is against the rules of their ancestors. For Orang Rimba, NPO should not try to control their life; on the contrary Orang Rimba also does not have the right to govern the state. Even some groups of Orang Rimba do not recognize the existence of the protected forest.

Other activities undertaken by Orang Rimba was selling serpehan (selling wood/ timber to villagers with the price that can reach million rupiah), it is in line with the activity to open new land for farming and involve villagers such as Toha, Wawan and people from Lubuk Bumbun as the tauke/buyer of woods. In turn, when they need money, they sell their land that has been tilled for daily needs or to buy a vehicle. This activity invites the outrage of NPO, in 2013 the Orang Rimba impeded the NPO from entering the park. Besides that, they engaged in collective violence by attacking offices such as the resort at Pematang Kabau (Air Hitam District).

Not only engaged in clearing land and selling serpehan, Orang Rimba also sell cultivated land inside the area to villagers. They work to clear the farm land then plant it with rubber trees, and after rubber trees mature, they are sold to outsiders (village communities in the buffer zone). This activity was done continuously; they worked on a garden, cut down trees (serpehan), then planted plantation crops. Because they want to get big profits instantly, selling land is the primary choice. These activities are done on an ongoing basis; the option to debate the zoning system is no longer considered. They oppose national park management policies through actions to take advantage of national parks.

Conflict becomes multidimensional when other parties become involved indirectly in the use of forest resources by appropriating the influence of the main conflict actors. Villagers living in buffer zones penetrate the forest and take forest resources out using access from Orang Rimba. Primarily, awareness has emerged toward the illegal actions, but the transformation of the forest into agricultural farms continues to be done. Local communities' resistance to forestry authorities' efforts to convert smallholder lands to timber plantations and, later, community involvement in 'forest management', is generally seen as an attempt to limit resource extraction from such periphery areas by the central elite (Kusworo, 2014).

Furthermore, government attempts at forest control have created conflict between state agencies and villagers over forest land. Small land holders who farm the land inside state forest boundaries in the region have been seen by Indonesian forestry authorities as perambah hutan (forest squatters/ encroachers/ destroyers). Villagers knew that farming the land inside state forest boundaries was illegal, yet they continued to transform forests into agricultural fields. For the latecoming landless migrants and the children of early migrants who aspired to become smallholder farmers, squatting on forest land was a way to gain access to farmland through non-market relations. Local people's resistance to the efforts of forestry authorities to transform smallholder fields into plantation forests and, more recently, community involvement in 'forest management', are generally viewed as efforts to restrict resource extraction from this sort of peripheral area by central elites (Kusworo, 2014).

\section{Contestation of the concept of national parks and customary forests}

The dynamics of conflict in the management of national parks that prioritize conservation aspects are the leading causes of disagreement between the state and indigenous peoples (Sardi, 2010). In addition, different ownership rights cause conflicts in the management of forest resources (Marina \& Dharmawan, 2011). In the BDNP context, the 
dynamics of conflict indicate that disagreements refer to the contestation between state power and customary power over the conservation area.

The NPO blocked various efforts to utilize forest resources through limitation activities on villagers who have gardens in the area. The Orang Rimba responded to this obstacle through the discourse of change from a national park to a customary forest where the management responsibilities were given to them. The Makekal United Group (MUG) youth, chaired by the Pengendum, for example, has refused NPM policies until the BDNPMP document is revised. MUG is a group that was born under guidance of NGO Sokola Rimba, its territory is in the Makekal river area. They advocate changing the status of the national park into customary forests designated for supporting the lives of the Orang Rimba. Customary forests are state forests that are handed over to the customary law community (recht-gemeenschap). These customary forests were previously called communal forests, clan forests, pertuanan forests, or other designations (Indonesia, 1999).

The same issue was developed by the Temenggung Tarib and his members, the customary forest discourse became stronger because it got support from the Indigenous Peoples Alliance of the Archipelago (IPAA) Jambi province and NGO remote indigenous community (RIC). Temenggung Tarib sought to get support from other stakeholders, but it was unsuccessful because, after a joint agreement, other groups focused more on the use of forest resources rather than conducting advocacy activities. Various efforts to change the concept of management of the national park has not been sucessful yet, because the government continued to maintain the management of the park based on the idea of conservation. This conflict continues and has not reached a compromise between the two sides involved in the battle.

\section{Conclusion}

The research objectiveswere mainly to understand the dynamics of the conflicts surrounding the protected area. Disagreement over the national park management has changed from the battle of the zoning system into claims based on traditional claims and state claims. In the beginning, the conflict contrasted the zoning system regulated by the NPO; in the next phase, the battle turned into a conflict of interest in access to use of the forest resources. Because the conflict was not resolved, the conflict turned into a debate over the concept between national parks and customary forests. This paper argues that the conflict in managing a national park is a battle that was contested for authority and power over the management system, forest resources, and debates the concept of forest management between the national park managed by state and customary forests managed by indigenous peoples.

Based on the conflict that occurred in BDNP, the alternative forms of conflict resolution such as community-based forest management need to be discussed and applied. Furthermore, the recognition of customary land based on the claims of Orang Rimba is also worth considering, since Orang Rimba is also an object and potential subject of conservation. Then the management of the national park can be directed to be managed together with the people who live in the protected area. The complexity of forest management such as what is occurring on the Bukit Duabelas and other national parks that accommodate indigenous peoples' existence needs further research.

\section{References}

Afiff, S., \& Lowe, C. (2007). Claiming indigenous community: Political discourse and natural resources right in Indonesia. Alternatives, 32, 73-79. doi: $10.1177 \% 2 F 030437540703200104$ 
Agung, P. (2011). Rencana tata ruang wilayah dan distribusi manfaat sumberdaya hutan. World Agroforestry Centre, (12), 1-4.

Anjarwati, E. (2008). Mainstreaming local wisdom: Indigenous people collective action in rainforest management (The Case of Indonesia and Philippines), 1-16. Retrieved from http://iasc2008. glos.ac.uk/conference papers/papers/A/ Anjarwati_207101.pdf

Balai Taman Nasional Bukit Duabelas. (2009). Laporan Sosialisasi dan Konsultasi Publik Penempatan Zonasi Taman Nasional Bukit Duabelas (Rep.). Jambi, Indonesia. Balai Taman Nasional Bukit Duabelas.

Bakker, L., \& Moniaga, S. (2010). The space between: Land claims and the law in Indonesia. Asian Journal of Social Science, 38, 187-203. doi: 10.1163/156853110X490890

Beckert, B., Dittrich, C., \& Adiwibowo, S. (2014). Contested land: An analysis of multi-layered conflicts in Jambi Province, Sumatra, Indonesia. ASEAS - Austrian Journal of South-East Asian Studies, 7(1), 75-92. doi: 10.14764/10.ASEAS-2014.1-6

Cote, D. J., \& Cliche, L. (2011). Indigenous peoples' resistance to oil palm plantation in Borneo. Kasarinlan: Philippine Journal of Third World Studies, 26(1-2), 121-152.

Darmanto. (2011). Konservasi global, taman nasional dan praktek lokal di pulau Siberut, Sumatera Barat. Jurnal Ilmu Kehutanan, V(1), 52-65. doi: 10.22146/ jik.582

Drahmoune, F. (2013). Agrarian transitions, rural resistance and peasant politics in Southeast Asia. Journal of Current Southeast Asian Affairs, 32(1), 111-139. doi: 10.1177/186810341303200105

Hammill, A., Craig, R., Malpas, R., \& Matthew, R. (2009). Conflict-Sesitive conservation practitioners' manual. Manitoba, Canada: International Institute for Sustainable Development.
Harun, M. K., \& Dwiprabowo, H. (2014). Model resolusi konflik lahan di kesatuan hutan produksi model Banjar. Jurnal Penelitian Sosial dan Ekonomi Kehutanan, 11(4), 265280. doi: 10.20886/jakk.2014.11.1.71-90

Constitution of the Republic Indonesia. (1999). Kehutanan (No. 41/1999). Indonesia: House of Representatives.

Jemahat, L., \& Si, P. K. (2018). Dinamika konflik sosial berakar tanah komunal di kabupaten Manggarai Flores. Sosio Konsepsia, 8(01), 45-59. doi: 10.33007/ska. v8i1.1544

KomnasHAM. (2007). Laporan akhir pemantauan dugaan pelanggaran hak masyarakat adat Orang Rimba. Jakarta: KomnasHAM.

Kusworo, A. (2014). Resource control, conflict, and collaboration. In A. Kusworo (Ed.), Pursuing livelihoods, imagining development (pp. 93-109). Australia: ANU Press.

Larson, A. M. (2013). Hak Tenurial dan akses ke hutan manual pelatihan untuk penelitian. Bogor, Indonesia: CIFOR.

Marina, I., \& Dharmawan, A. H. (2011). Analisis konflik sumberdaya hutan di kawasan konservasi. Sodality: Jurnal Transdisiplin Sosiologi, Komunikasi, Dan Ekologi Manusia, 05(01), 90-96. doi: 10.22500/sodality.v5i1.5830

Matland, R. E. (1995). Synthesizing the Implementation literature: The ambiguityconflict model of policy implementation. Journal of Public Administration Research and Theory: J-PART, 5(2), 145-174. doi: 10.1093/oxfordjournals.jpart.a037242

Prabowo, S. A., Basuni, S., \& Suharjito, D. (2010). Konflik tanpa henti: Permukiman dalam kawasan taman nasional halimun salak. Jurnal Manajemen Hutan Tropika, XVI(3), 137-142.

Pruitt, D. G., \& Rubin, J. Z. (2004). Teori konflik sosial. Yogyakarta: Pustaka Pelajar.

Purnomo, E. P., \& Anand, P.(2014). The conflict of forest tenure and the emergence of 
community based forest management in Indonesia. Jurnal of Government and Politics, 5(1), 20-31. doi: 10.18196/ jgp.2014.0003

Ribot, J. C., \& Peluso, N. L. (2003). A theory of access. Rural Sociology, 68(2), 153-181. doi: 10.1111/j.1549-0831.2003.tb00133.x

Rokhdian, D. (2012). Alim Rajo disembah, piado alim rajo disanggah: Ragam bentuk perlawanan orang rimba makekal hulu terhadap kebijakan zonasi Taman Nasional Bukit Duabelas, Jambi (Unpublished master's thesis). Universitas Indonesia.

Sardi, I. (2010). Konflik sosial dalam pemanfaatan sumberdaya hutan (Study kasus di taman Nasional Bukit DuaBelas Provinsi Jambi) (Unpublished master's thesis). Institut Pertanian Bogor.

Sembiring, E., Basuni, S., \& Soekmadi, R. (2010). Resolusi konflik pengelolaan Taman Nasional Teluk Cenderawasih di Kabupaten Teluk Wondama. Jurnal Manajemen Hutan Tropika, XVI (2)(2), 84-91.

Senjaya, B. (2011). Resistensi orang rimba (Studi tentang perlawanan Orang Rimba menghadapi kebijakan rencana pengelolaan Taman Nasional Bukit Duabelas Propinsi Jambi) (Unpublished master's thesis). Universitas Gadjah Mada.

Stark, S., \& Torrance, H. (2005). Case study. In B. Somekh \& C. Lewin (Eds.), Research Methods in the Social Sciences (1st ed., pp. 33-40). London, New Delhi: SAGE Publications.

Steinebach, S. (2013). "Today we Occupy the Plantation-Tomorrow Jakarta": Indigeneity, Land and Oil Palm
Plantations in Jambi. In B. HauserSchäublin (Ed.), Adat and Indigeneity in Indonesia: Culture and Entitlements between Heteronomy and Self-Ascription (pp. 63-79). Göttingen: Universitätsverlag Göttingen. Steinebach, S., \& Kunz, Y. (2017). Separating sisters from brothers: Ethnic relations and identity politics in the context of indigenous land Titling in Indonesia. Austrian Journal of South-East Asian Studies, 10(1), 47-64. doi: 10.14764/10.ASEAS-2017.1-4

Susan, N. (2009). Sosiologi Konflik dan Isu-isu Kontemporer. Jakarta: Kencana.

Sylviani. (2008). Kajian dampak perubahan fungsi kawasan hutan terhadap masyarkat sekitar. Penelitian Sosial dan Ekonomi Kehutanan, 5(3), 155-178. doi: 10.20886/jpsek.2008.5.3.155-178

Takiddin. (2014). Nilai-nilai kearifan budaya lokal orang rimba (Studi pada suku minoritas rimba di Kecamatan Air Hitam Provinsi Jambi). Jurnal Sosio Didaktika, 1(2), 161-170. doi: 10.15408/sd.v1i2.1258

Veeger, K. J. (1990). Realitas sosial, reflekasi filsafat sosial atas hubungan individu-masyarakat dalam cakrawala sejarah sosiologi. Jakarta: Gramedia.

Yasmi, Y., Guernier, J., \& Colfer, C. J. (2009). Positive and negative aspects of forestry conflict: Lessons From a decentralized forest management in Indonesia. International Forestry Review, 11(1), 98110. doi: 10.1505/ifor.11.1.98

Yasmi, Y., Kelley, L., \& Enters, T. (2011). Forest conflict in Asia and the role of collective Action in its management. Communications, (102), 30. doi: 10.2499/CAPRiWP102. 